\title{
Direct, maternal and cytoplasmic variance estimates of egg production traits in laying hens ${ }^{*}$
}

\author{
T. Szwaczkowski ${ }^{1}$, M. Bednarczyk ${ }^{2}$ and K. Kielczewski ${ }^{2}$ \\ 'Department of Genetics and Animal Breeding, \\ August Cieszkowski Agricultural University \\ Wotynska 33, 60-637 Poznani, Poland \\ 'Research Institute of Animal Production, Poultry Research Branch \\ Zakrzewo n/Poznań, 62-069 Palędzie, Poland
}

(Received 18 March 1999; accepted 7 October 1999)

\begin{abstract}
Initial egg production (IEP), egg weight (EW) and body weight (BW) of four laying hen lines were studied. A total of 74044 individuals from six selected generations were included in the analysis. The data (after Box-Cox transformation) were used to estimate direct and matcrnal additive genetic variances as well as cytoplasmic variances. Estimation of variance components was performed by the derivative-free REML programs of Meyer (1989). The largest genetic variance component estimates were obtained for IEP. However, the contributions of variances from both maternal (indirect) and cytoplasmic effects to phenotypic variance were very small for all analyzed traits. It was concluded that the maternal and cytoplasmic effects studied may be omitted in laying hen genetic evaluation.
\end{abstract}

KEY WORDS: anima! model, cytoplasmic effects, maternal effects, laying hens

\section{INTRODUCTION}

Classical genetic evaluations of livestock based on best linear unbiased prediction under an animal model usually ignore effects other than direct additive ones. On the other hand, several authors have reported the significance of other genetic effects in livestock and poultry performance traits (Wei and Van der Werf, 1993; Albuquerque et al., 1998; Mannen et al., 1998). Inclusion of non-additive and

\footnotetext{
- Supported by the State Committee for Scientific Research, Grant No 5 PO6D 03611
} 
maternal (indirect) effects in a genetic model influenced, among others, unbiased heritability estimates in the narrow sense, and more precise prediction of breeding values, as well as the use these effects through special crossbreeding strategy (Wei and van der Werf, 1993).

Evidence of maternal effects (excluding the inherited sample half of the dam's nuclear genes) on chicken performance traits has been shown in many studies (Chambers, 1990; Barbato and Vasilatos-Younken, 1991; Szwaczkowski, 1995; Koerhuis and Thompson, 1997). The majority of these conclusions are based on crossbreeding experiments. Another approach to the inference about matcrnal effects was a comparison of dam and sire variances in a conventional two-step hierarchic model (Wężyk, 1970). Unfortunately, these methods supply only general information (under strong conditions) on the maternal effects and some non-additive direct genetic variances (Tempelman and Burnside, 1990). Application of mixed model methodology allows estimation of the maternal variance components and respective effects (Van Vleck, 1993). These maternal genetic effects are usually classified as indirect and cytoplasmic. Biological mechanisms to explain these indirect maternal effects include egg environment during embryo development (incubation). Indirect maternal effects are divided into additive, dominance, additive by additive, etc. The confounding of the two contributions from the dam entails the possibility of a genetic correlation between the respective direct and maternal effects (Willham, 1980).

As already mentioned, another source of maternal effects are mitochondrial DNA (mtDNA) (Wagner, 1972). Ovum cytoplasm contains about one hundred thousands copies of mtDNA (whereas a male cell contains 70-100 copies). The mitochondrial genotype is transmitted only from female parents to their offspring (Wagner, 1972). A polymorphism of maternal lineages seems to result, first of all, from a mutational event as well as interaction of extranuclear and intranuclear DNA. A majority of the studies performed were carried out in mammals. However, the presence of cytoplasmic genetic effects has been also hypothesized in birds (Glaus et al., 1980; Buss, personal communication).

The objective of this study was to estimate direct additive, and maternal (indirect) additive variances and correlations between the direct and maternal additive effects as well as the cytoplasmic variances of some productive traits in laying hens.

\section{MATERIAL AND METHODS}

\section{Data description}

Four laying hen lines of Rhode Island Red (denoted as: K66, K44) and Rhode Island White (denoted as: A88 and A22) from six generations under selection 
(1991-1996) were studied. All recorded birds were maintained in a pedigree farm of the Poultry Research Branch in Zakrzewo (Poland). Both Rhode Island Red lines (as paternal) and Rhode Island White lines (as maternal) are used to produce commercial crosses. The following three performance traits were included: initial egg production (until week 36) (IEP), egg weight at week 33 (EW) and body weight at week $20(\mathrm{BW})$. The numbers of recorded individuals as well as brief statistical characteristics of these data-sets are given in Table 1.

TABLE 1

Description of the data

\begin{tabular}{cccccc}
\hline Strain/trait & $\begin{array}{c}\text { Numbers } \\
\text { of individuals } \\
\text { (observations) }\end{array}$ & \multicolumn{2}{c}{ Average/SD } & Skewness & Kurtosis \\
\hline K66 IEP, \% & 14755 & 88.7 & 14.3 & 0.00092 & 0.0137 \\
EW, g & 14583 & 60.5 & 4.5 & 0.00768 & 0.2185 \\
BW, g & 15686 & 1605 & 168 & 0.01383 & 0.5067 \\
& & & & & \\
K44 IEP, \% & 16192 & 89.0 & 14.9 & 0.00016 & 0.0083 \\
EW, g & 16011 & 60.3 & 4.7 & 0.00099 & 0.2578 \\
BW, g & 17299 & 1594 & 158 & 0.02906 & 0.4562 \\
A88 IEP, \% & 18976 & 87.7 & 17.0 & 0.02257 & 0.0002 \\
EW, g & 18750 & 59.3 & 4.7 & 0.00788 & 0.2673 \\
BW, g & 20064 & 1539 & 173 & 0.02146 & 0.1518 \\
A22 IEP, \% & 20323 & 83.9 & 17.2 & 0.00216 & 0.0145 \\
EW, g & 20088 & 59.9 & 4.2 & 0.00310 & 0.2185 \\
BW, g & 20995 & 1531 & 166 & 0.00587 & 0.3202 \\
\hline
\end{tabular}

\section{Data transformation}

Prior to analysis, the normality of trait distributions was examined. The skewness and kurtosis coefficients are given in Table 1. As expected, the analyzed traits have been shown to exhibit non-normal distributions. Hence, to reduce non-normality the Box-Cox power transformation (Box and Cox, 1964; Besbes et al., 1993) was employed. Each data-set was transformed for $t$ from a range of -5 to 5 using a step size of 0.1 and its skewness (first parameter analyzed) and kurtosis (second parameter analyzed) were calculated. The range of $t$ value was determined after previous studies (Beaumont, 1991; Szwaczkowski et al., 1994). For comparison of results between different traits, each transformed observation was divided by the strain-trait mean. 


\section{Genetic model}

The following linear unitrait individual animal model was fitted to the data:

$$
\mathbf{y}=\mathbf{X b}+\mathbf{Z a}+\mathbf{W} \mathbf{m}+\mathbf{T} \mathbf{c}+\mathbf{e}
$$

where: $\mathbf{y}$ is the observation vector; $\mathbf{b}$ is a vector of fixed effects (generation $\mathbf{x}$ hatch period); $\mathbf{a}$ is a vector of random direct additive genetic effects; $\mathbf{m}$ is a vector of random maternal additive genetic effects; $\mathbf{c}$ is a vector of random cytoplasmic effects; $\mathbf{e}$ is a vector of random errors; $\mathbf{X}, \mathbf{Z}, \mathbf{W}$ and $\mathbf{T}$ are the known incidence matrices. The model holds the following assumptions:

$$
\mathrm{E}\left[\begin{array}{l}
\mathbf{a} \\
\mathbf{m} \\
\mathbf{c} \\
\mathbf{e}
\end{array}\right]=\left[\begin{array}{l}
\mathbf{0} \\
\mathbf{0} \\
\mathbf{0} \\
\mathbf{0}
\end{array}\right] \text { and } \mathrm{D}\left[\begin{array}{l}
\mathbf{a} \\
\mathbf{m} \\
\mathbf{c} \\
\mathbf{e}
\end{array}\right]=\left[\begin{array}{cccc}
\mathbf{A} \sigma_{\mathrm{a}}^{2} & \mathbf{A} \sigma_{\mathrm{am}} & \mathbf{0} & \mathbf{0} \\
\mathbf{A} \sigma_{\mathrm{am}} & \mathbf{A} \sigma_{\mathrm{m}}^{2} & \mathbf{0} & \mathbf{0} \\
\mathbf{0} & \mathbf{0} & \mathbf{I}_{1} \sigma_{\mathrm{c}}^{2} & \mathbf{0} \\
\mathbf{0} & \mathbf{0} & \mathbf{0} & \mathbf{I} \sigma_{\mathrm{e}}^{2}
\end{array}\right]
$$

In consequence:

$\mathrm{E}(\mathbf{y})=\mathbf{X} \mathbf{b}$ and

$\mathrm{D}(\mathbf{y})=\mathbf{Z A Z} \mathbf{Z}^{\prime} \sigma_{a}^{2}+\mathbf{W A W} \mathbf{W}^{\prime} \sigma_{m}^{2}+\mathbf{Z} \mathbf{A} \mathbf{W}^{\prime} \sigma_{a m}+\mathbf{W A Z} \mathbf{Z}_{a m}+\mathbf{T} \mathbf{T}^{\prime} \sigma_{c}^{2}+\mathbf{I} \sigma_{e}^{2}$,

where: $\mathbf{A}$ is the additive relationship matrix, $\mathbf{I}_{1}$ is the $1 \times 1$ identity matrix ( 1 is a number of maternal lineages - see below), $\sigma_{a}^{2}$ is the direct additive genetic variance, $\sigma_{m}^{2}$ is the maternal additive genetic variance, $\sigma_{a m}$ is the covariance between direct and maternal additive genetic effects, $\sigma_{e}^{2}$ is the error variance.

The levels of cytoplasmic effects were formed as maternal lineages (see e.g. Kennedy, 1985; Southwood et al., 1989). Thus, all recorded descendants of the oldest base dam (founder) were included in a single cytoplasmic group. The following genetic parameters were estimated: direct additive heritability $\left(h_{a}^{2}=\sigma_{a}^{2} / \sigma_{p}^{2}\right)$, maternal additive heritability $\left(h_{n}^{2}=\sigma_{m}^{2} / \sigma_{p}^{2}\right)$, cytoplasmic heritability $\left(h^{2}=\sigma_{c}^{2} / \sigma_{p}^{2}\right)$ and correlation between direct and maternal additive effects $\left(\mathrm{r}_{\mathrm{am}}=\sigma_{\mathrm{am}} / \sigma_{\mathrm{a}} \sigma_{\mathrm{m}}\right)^{p}$.

\section{Applied algorithm}

The variance component estimates were obtained by application of the derivative-free restricted maximum likelihood (DFREML) algorithm described by Graser et al. (1987) and Meyer (1989) to include additional random effects. A value of $10^{-8}$ for the variance of the likelihood function values was used as the iteration stopping criterion. All analyses were restarted to check for the occurrence of local maxima until the log-likelihood did not change beyond the first decimal. The computations were performed using the DFREML package programs of Meyer (1993). 


\section{RESULTS}

Estimates of direct and maternal additive and cytoplasmic variances (times 10000 ) of the analyzed traits are shown in Table 2 . As already mentioned above, to compare variance component estimates of different traits, each observation (after transformation) was divided by the mean. The highest estimates of direct additive variances were obtained for IEP. In the case of all lines, the lowest estimated variances were for BW. Differences in additive direct variances between lines were also registered.

TABLE 2

Estimates of direct additive $\left(\sigma_{\mathrm{a}}^{2}\right)$ and maternal additive $\left(\sigma_{\mathrm{tr}}^{2}\right)$ variances $(\mathrm{x} 10000)$ as well as cytoplasmic $\left(\sigma_{\mathrm{c}}^{2}\right)$ variances $(\mathrm{x} 10000)$ of studied traits

\begin{tabular}{rrrl}
\hline Strain/Trait & \multicolumn{1}{c}{$\sigma_{\mathrm{a}}^{2}$} & $\sigma_{\mathrm{m}}^{2}$ & $\sigma_{\mathrm{c}}^{2}$ \\
\hline K66 IEP & 220.6708 & 17.8727 & 0.4480 \\
EW & 35.8525 & 0.0017 & 0.0128 \\
BW & 0.5890 & 0.0651 & 0.0007 \\
& & & \\
K44 IEP & 162.5877 & 7.7113 & 0.0769 \\
EW & 8.5040 & 4.2884 & 0.0637 \\
BW & 3.0425 & 0.0706 & 0.0001 \\
& & & \\
A88 IEP & 114.4425 & 4.4871 & 0.0445 \\
EW & 17.7361 & 0.3719 & 0.0020 \\
BW & 0.2486 & 0.0047 & 0.0001 \\
& & & 0.0002 \\
A22 IEP & 288.5839 & 13.8338 & 0.0093 \\
EW & 2.0683 & 0.1453 & 0.00004 \\
BW & 0.1886 & 0.0038 & \\
\hline
\end{tabular}

Estimates of maternal genetic variances were the lowest compared to those of direct variance. Relatively larger maternal variabilities were also obtained for initial egg production, whereas for BW these estimates were the lowest. Almost all cytoplasmic variances were very low. However, it seems that larger maternal additive variance estimates are probably combined with the magnitude of cytoplasmic variance estimates.

The ratios of these variance estimates, denoted as the respective heritability coefficients (direct additive, maternal additive, cytoplasmic heritability) as well as the correlation estimates between direct and maternal additive effects are presented in Table 3. The largest direct additive heritability was estimated for body weight 
TABLE 3

Estimates of direct $\left(h_{d}^{2}\right)$, maternal $\left(h_{m}^{2}\right)$ and cytoplasmic $\left(h_{c}^{2}\right)$ heritabilitics as well as their approximated standard errors (in parenthesis) and correlation $\left(r_{;[n]}\right)$ between direct and maternal effects for studied traits

\begin{tabular}{ccccc}
\hline Strain/Trait & $h_{u}^{2}$ & $h_{t+}^{2}$ & $r_{\text {ut }}$ & $h_{c}^{2}$ \\
\hline K66 IEP & $0.2583 \pm 0.0236$ & $0.0209 \pm 0.0067$ & -0.0617 & $0.0005 \pm 0.0010$ \\
EW & $0.5530 \pm 0.0348$ & 0.0000 & 0.2334 & $0.0002 \pm 0.0006$ \\
BW & $0.4399 \pm 0.0299$ & $0.0486 \pm 0.0099$ & -0.0425 & $0.0005 \pm 0.0010$ \\
& & & & \\
K44 IEP & $0.2390 \pm 0.0217$ & $0.0135 \pm 0.0051$ & 0.0115 & $0.0001 \pm 0.0004$ \\
EW & $0.4262 \pm 0.0291$ & $0.2149 \pm 0.0207$ & -0.0307 & $0.0032 \pm 0.0025$ \\
BW & $0.5117 \pm 0.0307$ & $0.0119 \pm 0.0046$ & 0.0151 & 0.0000 \\
A88 IEP & $0.2842 \pm 0.0218$ & $0.0111 \pm 0.0043$ & 0.0182 & $0.0001 \pm 0.0004$ \\
EW & $0.5653 \pm 0.0310$ & $0.0119 \pm 0.0045$ & 0.0145 & $0.0001 \pm 0.0004$ \\
BW & $0.5300 \pm 0.0290$ & $0.0100 \pm 0.0039$ & 0.0137 & $0.0001 \pm 0.0003$ \\
& & & & \\
A22 IEP & $0.2365 \pm 0.0192$ & $0.0113 \pm 0.0042$ & 0.0281 & 0.0000 \\
EW & $0.5202 \pm 0.0287$ & $0.0365 \pm 0.0076$ & -0.0050 & $0.0023 \pm 0.0019$ \\
BW & $0.5000 \pm 0.0276$ & $0.0100 \pm 0.0039$ & 0.0141 & $0.0001 \pm 0.0003$ \\
\hline
\end{tabular}

and egg weight due to relatively low residual variance estimates (compared to other traits). These heritabilities ranged from 0.4262 (EW of K44) to 0.5653 (EW of A88). The corresponding estimates for IEP were under 0.29 .

The maternal additive heritabilities of EW (for line K44) were considerably high (0.2149) compared to the estimates for other traits (not exceeding 0.1). Basically, the estimated correlations between direct and maternal additive effects are close to zero (both positive and negative correlations), except for EW of line K66. However, in this case the correlation is overestimated by very low maternal genetic variance.

For all traits, cytoplasmic line effects did not seem to be important. The socalled cytoplasmic heritability estimates did not exceed $1 \%$ and were close to their standard deviations.

\section{DISCUSSION}

As already mentioned, the maternal effects were usually evaluated via crossbreeding experiments (mainly, for broiler chickens). Thus, these effects are treated as fixed and, in consequence, their estimation requires no knowledge of the respective variance components. The maternal effects are usually larger than within 
selected lines and in field collected data. Since animal model REML estimates of maternal additive and cytoplasmic variances for laying hen performance traits are rarely available (Szwaczkowski, 1995), discussion is unavoidably restricted to general considerations concerning mainly the estimation of these variances. Several authors (Kennedy, 1986; Mannen et al., 1998) reported that an accurate estimation of maternal additive and cytoplasmic variances is difficult because proportions of variance shared by relatives may be small and confounded with other genetic or environmental effects. Biases of cytoplasmic variance estimates are probably caused by misidentification of mitochondrial genotypes. Polymorphism of maternal lineages results from a mutational event, the creation of maternal lineages seems rather arbitrary. On the other hand, Salehi and James (1997) reported that the number of generations influences the detection of cytoplasmic effects. Generally, they concluded that the power of detection was reduced with fewer data. It should be stressed that an evaluation of cytoplasmic effects based on maternal lineages leads to underestimation of the variance (Mannen et al., 1998). Hence, molecular techniques were developed to study mitochondrial DNA sequence variants (Loftus et al., 1994; Takeda et al., 1995). Therefore, individuals with the same mitochondrial type classified by D-loop sequence variants would have the same gene product in the coding regions influencing some traits. This approach used, first of all, in dairy and beef cattle leads to conclusions on the importance of cytoplasmic effects in several performance traits (Boettcher et al., 1996; Mannen et al., 1998). Unfortunately, to our knowledge, the mitochondrial chicken genome has not been mapped yet.

These variance estimates are also negligible in this work (except the egg weight of K44). In principle, the estimated maternal and cytoplasmic variances are similar to those described by Szwaczkowski (1995) in other strains of laying hens, also using an REML under an animal model. It seems that both maternal additive and cytoplasmic effects might be ignored in genetic evaluations in laying hens.

The heritability of egg production traits has been studied extensively. Generally, the heritability estimates obtained by foreign authors (see e.g. Hagger, 1994; Tixer-Boichard et al., 1995; Poggenpoel et al., 1996) are higher compared to those from Polish laying hen populations (Cywa-Benko and Wężyk, 1992; Szydłowski, 1998). In the case of other livestock species, a similar relationship has also been registered. Most likely, it resulted from relatively large environment variability. However, the direct heritability estimates obtained in this study are considerably higher than reported for other Polish flocks. Comparisons of the cited heritabilities should be careful, since different methods were employed. Moreover, many of the reported results were calculated on the original scale without undergoing any transformations.

From a practical point of view, the results indicate the possibility of a genetic improvement of these traits on the basis of an additive genetic model. 


\section{CONCLUSIONS}

Additive maternal genetic effects and covariance between maternal and direct genetic effects do not seem to contribute to the phenotypic variances of those traits. Participation of variances from cytoplasmic effects in phenotypic variances was very small and similar for egg production traits and the body weight of all analyzed lines. Generally, the results obtained in this study lead to the suggestion that the „additional" genetic effects may be omitted in laying hen genetic evaluations.

\section{ACKNOWLEDGEMENTS}

Authors are grateful to Dr. Karin Meyer for providing her DFREML programs. The computations were performed at the Poznań Supercomputer and Networking Center.

\section{REFERENCES}

Albuquerque L.G., Keown J.F., Van Vleck L.D., 1998. Variances of direct genetic effects, matcrnal genetic effects, and cytoplasmic inheritance effects for milk yield, fat yicld, and fat percentage. J. Dairy Sci. 8I, 544-549

Barbato G.F., Vasilatos-Younken R., 1991. Sex-linked and maternal effects on growth in chickens. Poultry Sci. 70, 709-718

Beaumont C., 1991. Comparison of Henderson's Method I and Restricted Maximum Likelihood estimation of genetic parameters of reproductive traits. Poultry Sci. 70, 1462-1468

Besbes B., Ducrocq V., Foulley J.L., Protais M., Tavernier A., Tixer-Boichard M., Beaumont C., 1993. Box-Cox transformation of egg production traits of laying hens to improve genetic parameter estimation and breeding evaluation. Livest. Prod. Sci. 33, 313-326

Boettcher P.J., Kuhn M.T., Freeman A.E., 1996. Impacts of cytopiasmic inheritance on genetic evaluation. J. Dairy Sci. 79, 663-675

Box G.E.P., Cox D.R., 1964. An analysis of transformations. J. Royal Stat. Soc. B26, 211-243

Chambers J.R., 1990. Genetics of growth and meat production in chicken. In: R.D. Crawford (Editor). Poultry Breeding and Genetics. Elsevier Science, Amsterdam (The Netherlands), pp. 599-643

Cywa-Benko K., Wężyk S., 1992. The phenotypic and genetic parameters in 4 laying hens strains selected by the same method and under the same management conditions. Procecdings of 19 th Congress of World's Poultry, Amsterdam (The Netherlands), p. 736

Glaus K.R., Zassenhause H.P., Fechheimer N.S. Perlmann P.S., 1980. Avian mtDNA: structure. organization and evolution. In: A.M. Kroon, C. Saccone (Editors). The Organisation and Expression of the Mitochondrial Genome. North Holland, Amsterdam (The Netherlands)

Graser H.U., Smith S.P., Tier B., 1987. A derivative-free approach for estimating variance components in animal model by restricted maximum likelihood. J. Anim. Sci. 64, 1320-1370

Hagger C., 1994. Genetic correelations between body weight of cocks and prodution traits in laying hens, and their possible use in breeding schemes. Poultry Sci. 73, 381-387 
Kennedy B.W., 1986. A further look at evidence for cytoplasmic inheritance for production traits in dairy cattle. J. Dairy Sci. 69, 3100-3105

Koerhuis A.N.M., Thompson R., 1997. Modeis to estimate maternal effects for juvenile body weight in broiler chickens. Genet. Sel. Evol. 29, 225-249

Loftus R.T., Machugh D.E., Ngere L.O., Balain D.S., Badi A.M., Bradley D.G., Cunningham E.P., 1994. Mitochondrial genetic variation in European, African and Indian cattle populations. Anim. Genet. 25, 265-271

Mannen H., Kojima T., Oyama K., Mukai F., Ishida T., Tsuji S., 1998. Effect of mitochondrial DNA variation on carcas traits of Japanese Black cattle. J. Anim. Sci. 76, 36-41

Meyer K., 1989. Restricted maximum likelihood to estimate variance components for animal models with several random effects using a derivative-free algorithm. Genet. Sel. Evol. 21, 317 340

Meyer K., 1993. Programs to estimate variance components for individual animal model by restricted maximum likelihood. User notes. Institute of Animal Genetics, Edinburgh University (Scotland)

Poggenpocl D.G., Ferreira G.F., Hayes J.P., du Preez J.J., 1996. Response to long-term selection for egg prodution in laying hens. Brit. Poultry Sci. 37, 743-756

Salehi A., James J.W., 1997. Detection of cytoplasmic effects on production: the influence of number of years of data. Genet. Sel. Evol. 29, 269- 277

Southwood O.I., Kennedy B.W., Meyer K., Gibson J.P., 1989. Estimation of additive maternal and cytoplasmic genetic variances in animal models. J. Dairy Sci. 72, 3006-3012

Szwaczkowski T., 1995. An analysis of the genetic determination of the performance traits in laying hens (in Polish). Rocz. Akad. Roln., Poznań, No 260

Szwaczkowski T., Wężyk S., Czeluśniak H., 1994.Transformations of performance trait data in laying hens. Rocz. Nauk. Zoot. 21 (1-2), 25-32

Szydlowski M., 1998. Detection of genes with large effects in laying hen populations (in Polish). Department of Genetics and Animal Breeding, August Cieszkowski Agricultural University of Poznań (Poland)

Takeda K., Onishi A., Ishida N., Kawakami K., Komatsu M., Inumaru S., 1995. SSCP analysis of pig mitochondrial DNA D-loop region polymorphism. Anim. Genet. 26, 321-326

Tempelman R.J., Burnside F.B., 1990. Additive and nonadditive genetic variation for production traits in Canadian Holstein. J. Dairy Sci. 73, 2206-2213

Tixer-Boichard M., Boichard D., Groeneveld E., Bordas A., 1995. Restricted maximum likelihood estimates of genetic parameters of adult male and female Rhode Island Red chickens divergently selected for residual food consumption. Poultry Sci. 74, 1245-1252

Van Vleck L.D., 1993. Estimation of nonadditive genetic variances for a total-merit model including maternal effects. J. Anim. Sci. 71, 2006-2011

Wagner R.P., 1972. The role of maternal effects in animal breeding: II. Mitochondria and animal inheritance. J. Anim. Sci. 35, 1280-1287

Wei M., Van der Werf J.H.J., 1993. Animal model estimation of additive and dominance variances in egg production traits of poultry. J. Anim. Sci. 71, 57-65

Wężyk S., 1970. Response to selection in closed laying hen flock (in Polish). Research Institute of Animal Production Press, Kraków (Poland)

Willham R.L., 1980. Problems in estimating maternal cffects. Livest. Prod. Sci. 7, 405-418 


\section{STRESZCZENIE}

Oszacowania wariancji genetycznej addytywnej bezpośredniej, matczynej i cytoplazmatycznej cech użytkowych kur nieśnych

Analizą objęto trzy cechy (nieśność początkową, masę jaja i masę ciała) 74044 kur nieśnych czterech linii, pochodzących z sześciu selekcjonowanych pokoleń (1991-96). Szacowano wariancję genetyczną addytywną bezpośrednią, matczyną i cytoplazmatyczną (poprzedzone transformacją danych w oparciu o metodę Boxa-Coxa) przy użyciu algorytmu największej wiarygodności z ograniczeniem ,wolnego od obliczania pochodnej” (DFREML). Największe estymatory wariancji genetycznych uzyskano dla cechy nieśność początkowa. Udział wariancji matczynej (pośredniej) i cytoplazmatycznej w wariancji fenotypowej dla wszystkich cech i linii był jednak mały. Efekty te mogą więc być pomijane w ocenie wartości genetycznej kur nieśnych w tych populacjach. 